\title{
THE HISTORICAL FUNDAMENTS OF VALEOLOGY
}

\author{
Asila Bakhtiyor kizi Sadikova \\ Teacher at the Department of National Idea and Basics of Spirituality and Law Studies
}

Article DOI: $\underline{\text { https://doi.org/10.36713/epra4054 }}$

\begin{abstract}
In this article have been investigated historical fundaments of valeology by the philosophical literatures and sources as well. Besides, research showed that human being connected his physical condition with mysterious imaginations when he was weak in front of the nature powers. During the primitive community period, it was expressed it's on eyes, the chores of protecting the health was expressed via religious ceremonies.
\end{abstract}

KEY WORDS: history, valeology, subject, philosophy, ancient time, knowledge, biology, medicine.

\section{INTRODUCTION}

The attitude of human health depends on living style and his own ability of doing biological and social duties since ancient times. It is naturally clear that, such kind of attitude respectively comes together with human anatomy and psychological features, the items which spoils normal working system of human body and other kinds of knowledge.

Human being connected his physical condition with mysterious imaginations when he was weak in front of the nature powers. During the primitive community period, it was expressed it's on eyes, the chores of protecting the health was expressed via religious ceremonies. But as a result of observing of his own life, human being noticed that health, lifestyle, dangerous items, herbal features of different items and reasonable connections.

The condition of the human being had been noticed with the connection of physical protection of himself, family and the tribe which he belongs to. Because of undeveloped medicine, people believed more the opportunities of his organism than his own treatment when he got ill and he lacked it the reasons of illness and mechanisms.

\section{METHODS}

During the period of slavery people tried to systemize the medical knowledge of human being. Mostly it was paid attention to more healthy life. As the fruit of the labour of Kon-Fusi by the Chinese (2600
BC), "Ayurveda" by the Indians (1800 BC), "About health life style" by Hippotrat. The main concept was not to treat the illness but developing human health, protecting, in case of bad medical conditions to use the reserved opportunities of health. According to the financial and social classification of the slavery society peoples attitude has been changed about human health. The messy lives of slave owners weren't medically acceptable and they called doctors as soon as they had health problem. As a result of this, medicine had lost its feature of avoiding and started basing on treating. Moreover, Far Eastern countries (e.g. china and India), specifically their becoming "Closed countries". anyway, we can see some scientist who researched about medicine in later centuries. For example, Abu Ali Ibn Sina (he was famous with the name "Avicena" in European countries) wrote "The laws of Medicine" to show that not treating illness but protecting the health to but protecting the health to live longer.

\section{RESULTS AND DISCUSSIONS}

The next steps of Civilization paid attention to treating the illness and it causes decreasing the attention to human health. It's true that, Ibn Sina, Bekon, Lomonosov, Mudrov and other scientists also mentioned that main attention should be paid to human health and prophylaxis but the subject doesn't choose this way.

At the end of $19^{\text {th }}$ century Mechnikov made a speech at the meeting of doctors (in 1883) about "The 
herbal power of organizm". In this speech he criticize the term "etiologic". He expressed the starting of illness because of combination of reason and the process of internal organism.

The 60 s of the $20^{\text {th }}$ century patalogic scientists Pavlenko and Obeynin started giving the explanation to mechanisms of human heath and ways of affecting on it. They proved the concept "sinology" (the attempt or organism against the illness). The 70-80s of this century militaries (Kaznecheev, Bersebeva and others) contributed much to the development of medicine. They started explaining the term donozologic diagnose". Brexman (1982) is a man who proved the methodological fundaments of protecting the health. The purpose of new strategy consolidating valeology, its theoretical and practical achievements [4].

\section{CONCLUSION}

Valeology has three directions:

a) To create theoretical fundaments of valeology, including age valeology, medical geneties, immunology, reproductive sexology, ecological valeology;

b) To prove scientifically to develop theoretical features of physical education, selfcontrolling of psykhosologic fundaments, all kinds of actions (labour and education);

c) To develop the vale logic education as a system of bringing up perfect people, increasing the recourses of health.

We can solve a several problems which are unsolvable e.g. developing the structure of health service and producing the technologies of health.

Valeology service includes 4 steps:

-pronostical screeming;

-searching the anomit of health the quality of it;

-choosing treating technologies;

-fulfilling the amount of health and quality.

It is believed that valeology will be effective way to treat health problems. If we don't do something about it, or if human health can't be problem of as a government affair, the society will face physical decrease.

\section{REFERENCES}

1. Vayner E.N. Healthy life-style-Moscow.

2. Gurevich P.S. Human philosophy. Chapter 1.

3. Tillaeva G. Education and upbringing: problem and solution.-Tashkent, 2000.

4. Philosophy textbook. Tashkent: Ukituvchi, 2001. 